\title{
SPEAKING TO EXPERTS AND PATIENTS: RECOMMENDATIONS FOR IMPROVING ANTIRETROVIRAL THERAPY (ART) ADHERENCE
}

\author{
Authors: \\ Janice Frank ${ }^{1}$ \\ Norman Duncan ${ }^{1}$ \\ Affiliations: \\ Department of \\ Psychology, University of \\ the Witwatersrand, \\ South Africa

\section{Correspondence to:} \\ Janice Frank \\ e-mail: \\ janice.frank@wits.ac.za

\section{Postal address:} \\ Department of \\ Psychology, University \\ of the Witwatersrand, \\ Johannesburg, Private Bag \\ X3, P. O. Wits, 2050, \\ South Africa
}

\section{Keywords:}

HIV/AIDS; antiretroviral medication; experts; patients; healthcare

Dates:

Received: 22 May 2008

Accepted: 03 Nov. 2008

Published: 08 May 2009

How to cite this article: Frank, J. \& Duncan, N., 2009, 'Speaking to experts and patients: Recommendations for improving antiretroviral therapy (ART) adherence', Health SA Gesondheid 14(1) Art. \#410, 9 pages. DOI: 10.4102/hsag.v14i1.410

\section{This article is available}

http://www.hsag.co.za
(C) 2009. The Authors. Licensee: OpenJournals Publishing. This work is licensed under the Creative Commons Attribution License.

\section{ABSTRACT}

This article reports on the findings of a study that aimed to explore experts' and patients' opinions and recommendations regarding adherence to antiretroviral medication. This study was prompted firstly by the lack of existing local research on adherence to antiretroviral therapy (ART) and secondly by the importance of adherence, given the recent introduction of ART to the public health sector. Four experts and seven patients were interviewed. The experts had worked within the HIV/AIDS field for at least two years while the patients (chosen from public antiretroviral roll-out programmes) had been on ART for at least six months. These interviews were transcribed and analysed using thematic content analysis. This article focuses specifically on the recommendations for improving adherence that emerged from the experts' and patients' interviews. While the experts and patients generated two fairly distinct sets of recommendations (clearly informed by their different experiences and knowledge), both groups emphasised the importance of the mediating effects of social support and the healthcare provider-patient relationship in adherence to ART medication.

\section{OPSOMMING}

Gesprekke met kundiges en pasiënte: Aanbevelings ter verbetering van ART-nakoming. Hierdie artikel doen verslag oor die bevindinge van ' $n$ studie wat kundiges en pasiënte se menings en aanbevelings ten opsigte van die nakoming van antiretrovirale medikasievoorskrifte ondersoek het. Die studie is in die eerste plek uitgevoer na aanleiding van die gebrek aan bestaande plaaslike navorsing oor die nakoming van antiretrovirale terapie (ART) en in die tweede plek na aanleiding van die belangrikheid van nakoming in die lig van die onlangse bekendstelling van ART in die openbaregesondheidsektor. Onderhoude is met vier kundiges en sewe pasiënte gevoer. Die kundiges het vir ten minste twee jaar binne die MIV/Vigs-omgewing gewerk en die pasiënte (wat uit die openbare antiretrovirale bekendstellingsprogramme gekies is) het ten minste ses maande van ART-terapie ondergaan. Die onderhoude is getranskribeer en met die gebruik van tematiese inhoudsanalise ontleed. Hierdie artikel fokus spesifiek op die aanbevelings vir die verbetering van nakoming wat uit die onderhoude met die kundiges en die pasiënte gespruit het. Terwyl die kundiges en die pasiënte twee redelik uiteenlopende stelle aanbevelings gemaak het (wat duidelik deur hulle onderskeie ondervinding en kennis beïnvloed is), het altwee groepe beklemtoon dat die bemiddelende effek van maatskaplike ondersteuning en die verhouding tussen die pasiënt en die voorsiener van gesondheidsorg ' $n$ belangrike rol speel in die nakoming van ART-medikasievoorskrifte.

\section{INTRODUCTION}

The introduction of highly active antiretroviral therapy (HAART) to the USA in 1996 led to a significant decline in HIV / AIDS-related morbidity and mortality in that country (Kimmerling, Wagner \& GhoshDastidar 2003:281-284; Stone \& Smith 2004:27s-29s). Although HIV requires consistent, long-term management, it is but a chronic condition (Buick et al. 2004:3-44). This transformation from deadly virus to manageable chronic illness is due to the significant viral suppression achieved by ART, although this can only be realised with high to maximum levels of adherence (Stone \& Smith 2004:27s-29s). Because the introduction of antiretroviral medication to the public health sector has been fairly recent, there appears to be little local research regarding adherence to antiretroviral medication. Hence, the primary aim of this study was to begin to bridge this gap by exploring the opinions of both experts working within the HIV/AIDS field and patients who are currently on antiretroviral medication regarding adherence to medication. A more practical aim of this study was to use the findings of this research to generate suggestions for antiretroviral adherence interventions.

Adherence or compliance is defined as the extent to which time history corresponds to a drug regimen (Chung et al. 2002:301-310). In other words, adherence refers to how closely patients follow their treatment programme (Haynes 2001). Adherence, specifically in relation to the treatment of HIV, is an issue of significant complexity for three main reasons. Firstly, HIV patients may have to take as many as 30 tablets a day, including a combination of antiretroviral medications, with numerous prophylactic medications for pneumonia, tuberculosis and other HIV-related illnesses. Secondly, certain types of medication may be associated with certain dietary restrictions, including taking some medication on an empty stomach. This means that it is necessary for HIV-positive patients to remember what medications to take at what times, and with what dietary restrictions. Thirdly, HIV medication regimens frequently have strong side effects, such as nausea and vomiting (Chung et al. 2002:301310; Ickovics \& Meade 2002:309-318). These factors will arguably influence patients' adherence to medication regimes significantly.

Maximum adherence to ARV regimens is crucial for three main reasons. Firstly, adherence to ARVs allows a patient to gain the full benefits of HAART, including viral load suppression, a reduced destruction of CD4+ cells, the promotion of immune system repair, and a slower progression to AIDS (Chung et al. 2002:301-310; Ickovics \& Meade 2002:309-318; Kimmerling, Wagner \& Ghosh-Dastidar 2003:281-284; Popp \& Fisher 2002:676-678). Secondly, sub-optimal adherence can promote the 
mutation of the HI virus, which could lead to the development of one or more resistant strains of the virus (Chung et al 2002:301-310; Ickovics \& Meade 2002:309-318, Kalichman \& Rompa 2003:59-61; Kimmerling, Wagner \& Ghosh-Dastidar 2003:281-284; Lucas, Wu \& Cheever 2004:173-180). Thirdly, failed treatment regimes increase the expenditure for healthcare services. Having to repeatedly treat non-compliant patients is costly. This is of particular relevance in South Africa, as this country already faces many challenges as a result of its underresourced healthcare infrastructure (Chung et al. 2002:301-310, Ickovics \& Meade 2002:309-318).

\section{PREDICTORS OF MEDICATION ADHERENCE}

There appears to be two broad categories of predictors of medication adherence: predictors related to the treatment regimen and predictors related to the individual.

\section{Complexity of the regime}

One of the challenges of adherence to antiretroviral (ARV) medication is the complexity of the medication regimen. This includes the difficulty some patients may experience as a result of having to ingest a variety of large pills (Mann \& Roberts 2000:377386), the strict dietary requirements associated with ARV treatment, as well as the associated side effects of the medication (Chung et al. 2002:301-310; Ickovics \& Meade 2002:309-318). The side effects of the medication include diarrhoea, fatigue, nausea, vomiting, peripheral neuropathy and metabolic changes (Max \& Sherer 2000:S96-S116). It has also been found that the perceived 'fit' of the medical regimen into the patient's lifestyle is a strong predictor of adherence (Gifford et al. 2000:386-395). Many patients have reported that the complexity of the drug regimen requires that they restructure their daily routine so that it fits in with their medication regimen, and that this has influenced adherence (Mann \& Roberts 2000:377-386).

\section{Predictors related to the individual}

Personality traits have generally not been found to be very reliable predictors of adherence. However, certain psychological states have been seen to affect patients' levels of adherence (Burke et al. 1998:5-31). In general, high levels of distress have been found to be associated with low levels of adherence (Burke et al. 1998:5-31; French et al. 2005:590-597). Emotional distress, specifically, has been found to serve as an indicator for healthcompromising behaviour, including lower levels of adherence (Kalichman \& Rompa 2003:59-61). The occurrence of posttraumatic stress disorder has also been found to predict poor health outcomes in HIV-positive patients, including poor levels of adherence (Brief et al. 2004:97-120). Burke et al. (1998:5-31) cite an association between depression and adherence in some (but not all) studies (Ickovics \& Meade 2002:309-318). Kalichman \& Rompa (2003:58-61) found that non-compliant patients scored higher on the Beck Hopelessness Scale, supporting a possible relationship between depression and adherence. Anxiety has also been found to be associated with adherence (Burke et al. 1998:5-31) due to the co-morbidity between depression and anxiety.

Patient perception of antiretroviral medication has also been identified as a predictor of adherence. Doubts about the efficacy of antiretroviral treatment as well as the medication serving as a constant reminder of their disease status have been cited as being strongly associated with non-adherence (Mann \& Roberts 2000:377-386). Chung et al. (2002:301-310) found that higher measures of self-efficacy (i.e., subjects being confident that they would be able to take all or most of their medication) predicted high levels of adherence. It has also been found that a strong belief in the development of resistant strains as a result of nonadherence has served as a positive motivator for adherence (Chung et al. 2002:301-310).

Drug and alcohol abuse has also been found to be associated with adherence levels (Ickovics \& Meade 2002:309-318; Kalichman \&
Rompa 2003:59-61; Shernoff 2001). The influence of alcohol and drug abuse can affect individuals' ability to remember to take their medication. Furthermore, substance abuse is viewed as a correlate of sexual risk practices in HIV-positive individuals, and thus may serve as an indicator of health-compromising behaviour, including poor treatment adherence (Kalichman \& Rompa 2003:59-61). In addition, it is also hypothesised that certain drugs and alcohol may interact with the antiretroviral medication, rendering the medication less effective. According to Rothlind et al. (2005:70-83) the occurrence of alcohol consumption $\mathrm{i}$ in HIV-infected individuals is associated with an increased risk of neuropsychological impairment and this could compromise a patient's capacity for adherence. The results of some studies have in fact revealed that participants using alcohol and/or drugs showed poorer adherence levels than those who did not use these substances (Berg et al. 2004:1111-1117; Heckman et al. 2004:219-230). However, Ware, Wyatt and Tugenberg (2005) note that stereotyping alcohol and substance users as poor adherers to medication may lead to an under-emphasis of the non-alcohol/drug-related factors affecting adherence.

A study carried out by Kalichman and Rompa (2003:59-61) identifies a relationship between adherence and sexual practice. Patients who reported a significantly greater number of sexual partners, greater rates of unprotected vaginal intercourse, including with partners who were HIV-negative or of unknown status, were more likely than others to be non-adherent.

Adherence is thus an issue of significant complexity due to a range of intervening psychological, treatment-related, behavioural, social and demographic variables. While perfect adherence is possible, given the multiplicity of variables involved in the treatment of HIV it is clearly a challenge (Chung et al. 2002:301-310).

\section{RESEARCH METHOD}

The study researched the fairly under-developed domain of adherence to anti-retroviral therapy, hence a qualitative approach was deemed appropriate. The study was exploratory in nature: it examined experts' and patients' perceptions of the barriers to adherence to ARVs and, on the basis of these perceptions, generated recommendations for the improvement of adherence levels. The study was aimed at understanding the perceptions and experiences of those currently on ART, as well as those that were deemed to be closely involved with ART intervention in a professional capacity. This was achieved through the investigation of patients' and experts' opinions and recommendations regarding adherence to ART by means of semi-structured interviews. The themes emerging from these interviews were subsequently analysed.

The specific research questions examined were: (a) What are the patients' perceptions of, and recommendations for, improving antiretroviral medication adherence? (b) What are the experts' perceptions of, and recommendations for, improving antiretroviral medication adherence?

\section{Sampling}

Participants were recruited by means of non-probability, purposive sampling. This method of sampling ensured that only those participants who were able to respond to the above research questions, according to specific criteria (discussed below), were chosen. The sample consisted of seven patients currently on ART and four experts working within the field of HIV/AIDS (see Table 1). An HIV/AIDS expert was defined as someone who had worked with patients with HIV, and specifically patients receiving antiretroviral medication, for at least two years. It was considered that two years was a sufficiently significant period of time for these interviewees to have acquired sufficient experience and knowledge to be in a position to articulate informed opinions and recommendations concerning adherence to ART. 
TABLE 1

Patient participant demographic information

\begin{tabular}{llll}
\hline & AGE & SEX & OCCUPATION \\
\hline Patient 1 & 28 & Male & Unemployed \\
Patient 2 & 38 & Male & Unemployed \\
Patient 3 & 32 & Female & Counsellor \\
Patient 4 & 35 & Female & Counsellor \\
Patient 5 & 35 & Female & Unemployed \\
Patient 6 & 45 & Female & Unemployed \\
Patient 7 & 29 & Male & Educator \\
\hline
\end{tabular}

TABLE 2

Medicine regimen of patients

\begin{tabular}{llll}
\hline & $\begin{array}{l}\text { DURATION OF } \\
\text { TREATMENT }\end{array}$ & $\begin{array}{l}\text { DOSAGE } \\
\text { (Number of } \\
\text { tablets or } \\
\text { amount of fluid } \\
\text { per day) }\end{array}$ & $\begin{array}{l}\text { LEVEL OF } \\
\text { ADHERENCE }\end{array}$ \\
\hline Patient 1 & 6 months & 7 & Never forgets \\
Patient 2 & Not stated & 5 & Never forgets \\
Patient 3 & 7 months & 12 & Never forgets \\
Patient 4 & 12 months & 4 & Has forgotten once \\
Patient 5 & 7 months & 45 ml of fluid & Has forgotten \\
Patient 6 & 60 months & 6 & Has forgotten \\
Patient 7 & 6 months & 5 & Never forgets \\
\hline
\end{tabular}

TABLE 3

Expert participant demographic information

\begin{tabular}{llll}
\hline Expert 1 & F & $\begin{array}{l}\text { DESCRIPTION OF } \\
\text { ORGANISATION }\end{array}$ & OCCUPATION \\
Expert 2 & $M$ & $\begin{array}{l}\text { Treatment Action } \\
\text { Campaign (TAC) }\end{array}$ & $\begin{array}{l}\text { Adherence programme } \\
\text { coordinator and counsellor } \\
\text { Project coordinator }\end{array}$ \\
Expert 3 & $M$ & Public hospital & $\begin{array}{l}\text { Medical doctor and head of } \\
\text { ARV roll-out programme }\end{array}$ \\
Expert 4 & $M$ & $\begin{array}{l}\text { Human Sciences } \\
\text { Research Council } \\
\text { (HSRC) }\end{array}$ & $\begin{array}{l}\text { Psychologist and social } \\
\text { researcher }\end{array}$ \\
\hline
\end{tabular}

An HIV / AIDS patient was defined as someone who had been on antiretroviral medication for at least six months. The researcher (the first author) considered that six months was a sufficiently significant period of time for the patient to have experienced the side effects and improvements (if any) associated with the ART, and hence to be in a position to provide insight into the use of ART.

The seven patients were chosen from two antiretroviral rollout programmes in South Africa. All patients were older than 18 years of age and reported to have been on ART for at least six months. While no measures of cognitive capacity were administered, the patients all presented as being cognitively able to participate in the interviews. Tables 1 and 2 reflect the patients' demographic information and medication regimes, respectively.

The four experts were chosen from different healthcare institutions within the Johannesburg and KwaZulu-Natal regions. Table 3 reflects the expert participants' demographic information.

\section{Data collection}

In exploratory research, the research area is one that is generally so unfamiliar that it becomes difficult to schedule a structured interview. The semi-structured interview employed was developed based on the existing literature and sought to obtain information relating to adherence to ARV medication. It was felt that such a technique would extract the participants' experiences that were significant to them, thus adding to our understanding of their responses to the medication. This type of interview technique allowed the researcher to explore emotions and convictions, thus adding to the richness of the experiences being explored.

Two separate interviews for the experts and the patients were developed. Each interview was developed in a manner that allowed the researcher to access experiences, opinions and information that a specific category of participant could offer. In addition, consideration was given to language usage in the development of the interview schedule. Specifically, patient interview schedules comprised questions that were structured in a manner that would make them easy to be understood, even by interviewees with only a basic education.

\section{Analysis of data}

The interview tape recordings were transcribed verbatim, with no additions or omissions made to the text. English was not the first language of some participants, and even though their narratives contained poor grammar they were still captured verbatim. Some emphasis was also placed on the manner in which participants shared their information, hence repetitions and pauses, for example, were also captured in the transcription.

A thematic content analysis was chosen as the method by which to analyse the interviews. Thematic content analysis provides a systematic method of examining and presenting interview content by identifying themes within the interviews (Titscher et al. 2000:56-71). With widespread ART having been introduced only recently in South Africa, the issue of adherence to antiretroviral medication is a relatively recent concern, and it was the aim of this research to ascertain what experts and patients perceived as possible barriers to adherence to antiretroviral medication as well as their recommendations for improving adherence. Although content analysis is limited in its ability to provide an in-depth analysis of the discursive texts it sufficed for the purposes of this primarily exploratory research study.

The data were categorised into themes as a starting point for the analysis. These categories were initially developed by the researcher and then checked independently by the second author (who served as the moderator) to ensure their accuracy and appropriateness. The process of categorising the information began with extracting themes that emerged from the interviews. This was done separately for the patients and the experts. The themes were then re-analysed by the moderator and it was found that the themes, in the main, were logical and coherently constituted. This process of systematically conceptualising the different categories was done recursively and resulted in an end product of four broad themes, namely, experts' perceptions of barriers to adherence, patients' perceptions of barriers to adherence, experts' recommendations for improving adherence, and patients' recommendations for improving adherence. Each of these themes consisted of various sub-themes.

This article focuses on the themes, the experts' recommendations for improving adherence and the patients' recommendations for improving adherence. The other two themes are reported on elsewhere (Frank 2006:31-72). 


\section{A note on issues of validity and reliability}

While mindful of the contestations concerning the use and appropriateness of the notions of validity and reliability in qualitative research (Tindall 2006:142-159), adequate attention was afforded to these issues in this study. In the main, an attempt was made to assure reliability through the meticulous recording of the research processes, the consistency of interview questions and the accuracy of transcriptions inter alia (see Silverman 1999:144-170). Cognisant of Reason and Rowan's observation (in Tindall 2006:157) that validity in qualitative research is inextricably 'tied up' with the experiences and social location of the researcher, an attempt was made in this study to enhance the validity of the data collection and analytical methods employed through close and consistent attention to reflexivity. Of course, the provision of excerpts from participants' interviews in this article also has a validation function in that it provides the reader with an opportunity to scrutinise the plausibility or appropriateness of the analyses conducted and the interpretations arrived at.

\section{FINDINGS \\ Contextualising the findings}

The research findings are presented in two sections: recommendations emerging from the expert interviews, and recommendations emerging from the patient interviews. While this article focuses on the recommendations of a group of AIDS patients and experts for improving ARV adherence, it was decided to introduce this section with a brief summary of some of the findings on the perceived barriers to ARV adherence that had emerged from the broader study (Frank 2006:31-72) on which this article is based, so as to contextualise the discussions that will follow.

Factors influencing adherence according to the expert group The experts highlighted a lack of disclosure as decreasing levels of adherence, as this reduced the extent of support that a patient was able to access. Stigma and discrimination were also highlighted as barriers to adherence, particularly insofar as these processes often result in reduced support. The experts felt that psychological factors such as co-morbid depression and anxiety may complicate a patient's adherence levels. The challenges facing specific communities were also highlighted. These included prison communities whose adherence to their medication regime was dependent on the cooperation and goodwill of the prison authorities. With reference to cultural factors, the experts felt that the influence of traditional medicine, as well as the Church, could compete with medical advice and affect patients' levels of adherence. In addition, the experts also argued that socio-economic issues in the country, including poverty and lack of education, were significant barriers to adherence. Finally, the expert informants also averred that many South African communities' tendency to doubt or question advice offered by medical practitioners may also contribute to patients following alternative treatments to ART. Obviously, the widely mediatised views of politicians, religious groups and traditional healers that oppose ARV treatment play an important role in this scepticism towards medical advice.

Factors influencing adherence according to patients

With regards to the medicine regimen, the patients felt that the quantity of medication, the dietary requirements associated with ART, and the side effects of the medication (ARV) were all barriers to adherence. In addition, alcohol and substance abuse, itinerant lifestyles, as well as a failure to take responsibility for one's life, were all contributors to poor adherence. It was also argued that once the disease symptoms had disappeared, patients were more likely to be non-adherent to their medication. Lastly, the patients stated that forgetfulness was also a significant barrier to adherence.

\section{Recommendations emerging from the interviews with the experts}

Fostering a warm healthcare provider-patient relationship

According to the expert participants, the relationship between the healthcare provider and the patient is a very significant mediator of adherence, as it has a direct influence on the patient's perceptions of illness and medication. In some cases, interaction with the healthcare worker is the point at which the patient first confronts issues related to the disease, such as infection and finding out his or her status. It was felt that this interaction would impact on future decision making and influence how the patient understands the illness, and how he or she chooses to treat it. This finding is echoed in the research of Meredith et al. (2001), who identified physicians as the source that most influences a patient's decision making in respect of medication. Along similar lines, Godin et al. (2005:493-519) claim that satisfaction with the physician-patient relationship is an important mediator of adherence (Heckman et al. 2004:219-230; Murphy et al. 2004:471-484).

Moreover, Expert 3 felt that the healthcare provider-patient relationship should be such that the patient feels comfortable enough to voice any concerns, including those about controversial issues such as traditional medicine.

'I think if you can develop a heal thcare provider-patient relationship where there's an open, warm, understanding and communication between the two groups, and there is an element of trust both ways, and the patient feels well informed, and he feels very much included in the team and has an opportunity to voice his concerns, his problems at home and any barriers that he or she might think that might impact on the adherence; those will be very important things, and one of the most important factors of adherence is that relationship between the healthcare provider and the patient.'

(Expert 3)

An extension of this idea would be that adherence interventions would have to be directed not only at patients, but also at healthcare providers. This means that perhaps healthcare providers may need ongoing in-service sensitivity training on how to foster relationships that would facilitate a more open discussion of issues related to HIV.

\section{Attending to mental health issues}

The relationship between HIV and psychological states cannot be denied. This is covered extensively in the literature (Brief et al. 2004:97-120; Halkitus, Kutnick \& Slater 2005:455-458; Ickovics \& Meade 2002:309-318; Kalichman \& Rompa 2003:59-61; Malan 2003:377-386; Moosa, Jeenah \& Vorster 2005:12-15; Phillips et al. 2005:273-293; Shernoff 2001; Yun et al. 2005:432-438). The literature also indicates that mental health care is significantly associated with adherence levels (Turner et al. 2003:248-257).

Not surprisingly, in this study, the experts felt that consideration of mental health issues was important in encouraging adherence.

'So I think again that it comes back to the individual. And as a way we know about introverts and extroverts - all those people. I prefer extroverts a lot, because they can talk about everything. When they are angry you know they are angry, they can fight with you, but tomorrow they have forgotten about it. They have cleaned their souls of everything."

(Expert 1)

Expert 1 stated that those who are aware of their emotions are more likely to voice their concerns and have fewer problems with issues of adherence. This implies that efforts to get patients more in touch with their emotions, such as psychotherapy, should be considered, along with the usual adherence counselling.

'What is one thing in particular is the finding and certainly my strong belief that if you are not psychologically well or 
psychiatrically well, it is going to have quite a bearing on whether you do continue to adhere to your medication or not. And the research seems to suggest that the people that are depressed don't really care all that much about their futures and so die, or not die, well, if I have to bounce that against side effects, against disclosure, against all the other negative things about being on ART, I would rather not.'

(Expert 4)

The expert participants stated that psychological interventions aimed at dealing with mental health issues would need to be in place as part of adherence interventions. This recommendation comes against the backdrop of recent studies identifying clinical depression as a possible mediator of adherence (see, for example, Brief et al. 2004:97-120; Halkitus, Kutnick \& Slater 2005:455-458; Turner et al. 2003:248-257; Yun et al. 2005:432-438). Some studies have revealed that antidepressant treatment improves levels of adherence in depressed patients (Turner et al. 2003:248-257; Yun et al. 2005:432-438). This means that perhaps a screening for clinical depression, for example, may be advisable when administering ART and that depressed patients may need to be directed toward antidepressant treatment and/or therapy in an effort to ensure maximum adherence levels.

\section{Strengthening social support}

Related to the theme described above, the experts stressed the importance of social support in maintaining good levels of adherence. This is supported by the literature. According to Godin et al. (2005:493-519), social support positively influences a patient's perception of the medication, and this in turn improves adherence. In a study of 113 patients it was found that relatively low levels of adherence were observed in those patients that did not belong to a support group (Berg et al. 2004:1111-1117). Kumarasamy et al. (2005:526-537) found that being able to turn toward family for support was a facilitator of good adherence levels. Three different sources of support were identified in the expert interviews, namely, support groups, family support and treatment supporters.

'That is why the support groups are so helpful to other people. We sit there thinking that they have the worst problem in the world, and then, they listen to other people's problems and they say, "Hey Cindy, I am much better. You see that beautiful lady. Yes, that lady has got so many problems. I am much better than her." Then you see something good happen to that person.'

(Expert 1)

It was felt that support groups are effective as they provide patients with the opportunity to be around individuals who are experiencing similar circumstances and, as a consequence, the possibility of witnessing experiences that are sometimes worse than their own. This serves a motivational function, as the afflicted individuals can see others, in similar or worse predicaments, that manage the illness, and this may inspire them to continue with their struggle.

'They must have a treatment supporter. Someone who is going to weekly monitor that person... Someone who is going to be there for you. Like a daughter supporter. Someone will come around and see that you did take your medication. "Do you feel well? Do you have any side effects?" Someone to give you the support, you know, so you can take your medication.'

(Expert 2)

The importance of using a treatment supporter (that is, an individual who is able to monitor the patient's treatment and provide support around any difficulties that may emerge) was also highlighted by the experts. This support system is currently used by the Treatment Action Campaign (TAC) (2006).

'I would also see that there is in place a friend or family member or a social contact that can help and I would establish a friendly relationship with the patient if possible, and create that sense of feeling that it is not a once-off thing. The patient is going to go home and there are going to be problems and there is an open door for discussion and the patient must feel that "If I have a problem, I can access help immediately, ask questions and get clarification".'

(Expert 3)

The importance of developing support in the home environment to facilitate dealing with problems as soon as they arise was also emphasised in the interviews with the experts. This may entail the healthcare provider's making contact with members of the patient's family, establishing rapport with them and educating them about issues of adherence (obviously while according due consideration to issues of ethics, such as patient confidentiality and consent). Since the family could serve as a support system, the feasibility and ethical desirability of adherence interventions including family members could perhaps be examined. This would be in keeping with the national guidelines on ART, which lists disclosure to at least one family member as an important psychosocial consideration in the management of ART (South African Department of Health 2004:n.p.).

\section{Promoting education}

The experts felt that education plays a significant role in whether patients adhered to their medication regimen or not.

'And get the education about taking the medication and the benefit of taking it... It's very important. Should the person start he must be told about adherence, when they started taking the treatment, they must continue. They have to be reminded at all times.

(Expert 2)

'In the antiretroviral therapy context, to make sure that the patients understand themselves, everything.

(Expert 3).

Educating patients on antiretroviral therapy would let them to better understand their illness and possibly ensure their continuing with the medication as prescribed. This would enable them to make better sense of the conflicting messages to which they may be exposed, thereby possibly boosting levels of adherence.

Expert 2 stressed that stigmatisation was a function of a lack of understanding of the virus at community level. From this it follows that an increased focus on psycho-education at the level of the community may be important. The aim of such an intervention would be to increase awareness and, as a consequence, possibly decrease the stigma associated with the disease, ultimately resulting in better support systems for patients to draw on.

\section{Harnessing traditional medicine and familial and religious practices}

The consideration of alternative sources of knowledge (alternative to mainstream medicine as a source of knowledge) may be important in future adherence education interventions. Furthermore, further research along this avenue could also help us to understand why certain patients are more accepting of opinions that appear to oppose ART. The following quote highlights the experience of patients who decide to adopt views and practices that conflict with ART adherence, despite having been exposed to ART adherence education.

'You know the main problem we find with our patients is they start perfectly but when they go out, they listen to other people. They had heard somebody saying this thing about the ARVs; that once you start taking this, you will start to feel well but then you are going to be forsaken and terminally ill, and you will die. Although they did the adherence and they understand the information correctly, but you know the power of the mind, because now, they are alone. The counsellor is no longer there, the sister from the clinic is no longer there. There they are amongst the people that are anti-ARV, so they put all those negative things, and then they believe that this is going to happen to them.'

(Expert 1)

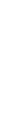


The decision to listen to family members as opposed to the medical professionals is also an area that warrants further research. It is hypothesised that respect for one's elders - an acknowledgement of their wisdom and financial dependence may mediate such decisions.

The study on which this article is based found that the Church may also be a source of messages that conflict with the ARV rollout campaign (Frank 2006:31-72).

'There are some churches where you find 'forced fasting'. Maybe they say you are praying so we have to have a 7 day dry fast, and some of them take their fast in church; you have to go to church and they have to keep on praying, so that HIV person will also have to. It is not easy to keep those things when you are sick...They think the prayer is much more effective if you fast..

We find that they went to a church, where they are told, "There is no HIV! You just have to pray, and then it will go away." There was another lady on Monday, she was told to come and test three times and on the third time she will be negative. We had to sit down with her and tell her the truth... That is why there are so many churches coming up... so many churches. And if you look at their brochures, when they write there, they can do a miracle healing, e.g., HIV, diabetes, they know that the people are desperate and they will go.

(Expert 1)

Thus, it appears as though it would be useful for educational interventions to be extended to the key institutions in the patient's life.

\section{Increased support among alcohol and substance users}

As noted earlier, several studies indicate an association between alcohol or substance use and adherence (e.g. Heckman et al. 2004:219-230; Ickovics \& Meade 2002:309-318; Kalichman \& Rompa 2003:59-61; Rothlind et al. 2005:70-83; Shernoff, 2001:n.p; Ware, Wyatt \& Tugenberg 2005:576-578). Given the manifestly negative effects of alcohol and drugs on medication compliance, it may be advisable for healthcare professionals to screen for alcohol and substance dependency prior to administering ART, and possibly also to prescribe treatment for alcohol and substance dependency where required. The suitability of ART for those who are perceived to be either alcohol or substance dependent could then be reviewed after treatment for substance or alcohol abuse. However, a study carried out in Boston in 2005 revealed that treatment for alcohol and substance dependency on its own does not necessarily improve adherence levels. This finding supports the idea of supervised medication delivery and simplified medication doses as perhaps being equally important (Samet et al. 2005:83-93).

Nonetheless, the expert participants felt that alcohol and substance users may require additional support in order to enhance adherence.

'Obviously somebody who has an alcohol problem ... who has got an addiction problem, those are people who you need to do a really, really good assessments and definitely bring in support to help them with adherence.'

(Expert 3)

As with the experts' recommendations, the following section comprises recommendations that were directly cited in the patient interviews, as well as recommendations that were inferred from the discussion of the patients' perceptions of obstacles to adherence.

\section{Recommendations emerging from the interviews with patients \\ Witnessed improvements}

Five of the eight patient participants interviewed for this study indicated that witnessing the effectiveness of ARVs positively affected their adherence to their medication regimens. However, the literature that was surveyed did not cover this issue. Nonetheless, for the patients interviewed, witnessing improvements in their own health and the health of other people living with HIV as a result of ART appeared to serve as a strong motivation to adhere to their treatment. Perhaps those who have witnessed or experienced improvements could be encouraged and trained to be ART-adherence spokespersons or counsellors. Their stories could possibly serve to counteract the effects of conflicting messages as referred to in the experts' interviews.

'I start to be sick. I've got sores all over the body. And I came back to the hospital. Then, I used to come here to Helen Joseph and met another doctor. When I came, I met only one doctor. By that time they tell me, "You are very, very sick. Don't you think you must start taking ARVs?" "ARVs, what's that?" "It is the medication for HIV. You'll be better."...

So I took them from October, November, December, January, February, March, April. In April they sent me to come and collect them here from the hospital because government bring them to the hospital. And I start to take them from the hospital and up to now, I'm still fine...It works because at that time I was losing lots of weight. I was wearing size 28. By that time I was having lots of sores, but now I'm fine.'

(Patient 3)

The above represents a patient's account of witnessed improvement of physical health due to ART. Such improvements vary, from the disappearance of stomach ailments and body sores to weight gain, and an improvement in general functioning. At the time of the interviews the patients who were persuaded of the effectiveness of ART reported maximum compliancy, which leads to the credible assumption, therefore, that believing in the treatment plays an important role in the individual's levels of adherence. This has implications for further research. Should the belief in the efficacy of ART serve as a motivator of adherence levels, further research would need to investigate the various factors affecting patients' beliefs in efficacy.

Enhancing social support

One of the main motivators for disclosure, as highlighted by the expert narratives, is the potential acquisition of support to assist patients with taking their medication. At least one of the patient interviewees was quite emphatic that social support would improve patients' levels of adherence.

'Disclosure, it's very important, because if you know I am HIV and we are friends, and you come and visit me, and it is time we have to go somewhere, you'll tell me not to forget my tablets, so if you don't know, you won't tell me that.

(Patient 6)

From the above, it appears that having someone to assist you with taking the medication makes it that much easier to adhere. It is thus recommended that adherence interventions should continue to focus on generating support for patients. This may take the form of encouraging disclosure or engaging patients in support groups so that they may be exposed to other individuals in similar situations to themselves. However, patients must be encouraged to disclose their status only when they feel it is safe to do so. It is not uncommon to hear of HIV-positive individuals that have been victims of discrimination (Akula 2002:n.p.) and there is a real risk of patients being exposed to such discrimination following injudicious disclosure.

\section{Employing practical aids such as timing mechanisms}

Five patients found that time-keeping mechanisms helped them to remember to take their medication. The use of timekeeping devices to aid adherence is supported by the literature (Mannheimer, Hirsch \& El-Sadr 1998:585-586).

'Okay, see the nurse make the calendar... They tell me when to take the tablets. Then, we got the paper to make the calendar and it tell me when to come back. So, I know every day. And then I know not to forget. You see you take the tablet on the calendar.'

(Patient 2)

'By eight o'clock I know, when it's "Generations". Sometimes I'm watching news and when it's finished I know it is time to take the 
medication...Yes. Because sometimes you forgot to set cell phone. Sometimes, you don't have cell phone. So, sometimes you can use soapies or something else to remind yourself.'

(Patient 6)

The above excerpts demonstrate the usefulness of cellular phones to set reminders to take medication, as well as calendars to keep track of medication and appointments. A creative reminder appeared to be the association between a television programme that screens at the same time every day and taking one's medication. In general, patients found such timekeeping strategies very effective in reminding them to take their medication. However, the patient still has to remember to activate time-keeping devices such as their alarms. Thus, even though such strategies may help to improve adherence, they may not be sufficient in ensuring maximum adherence.

\section{Providing counselling}

Some of the patients felt that counselling could aid in improving patients' levels of adherence.

'I think people need to do counselling more especially. And their families, they need a workshop or something like that, and to take care of the patient or the person who is affected to see that the taking the tablets accordingly. You can even have a calendar just to tick. Have your taken the morning treatment/dose or evening dose? You should tick and see when you forgot to take the medication, so you must have a calendar and a person to assist him or her. Anyone... a sister, wife, husband.'

(Patient 7)

Patient 3 and Patient 7 felt that counselling to enhance adherence would be beneficial to the patient. Patient 3 highlighted that, in certain instances, a patient may still not entirely understand the dynamics of ARV medication, even after counselling. In such situations, she advised, it may be necessary for continuous psycho-education, at least until the patient had grasped the importance of maximum adherence. Patient 7 felt that counselling should include members of the individual's family, probably as a means of increasing the individual's social support system.

\section{Addressing conflicting messages}

Three recommendations emerged from the discussion in relation to conflicting messages about ART. It was felt that the patient may be able to deal with opinions opposing ART if the following were undertaken. Firstly, it is recommended that the political context in which perceptions of ART are situated must be considered in adherence interventions. This may mean that adherence interventions may have to nurture attitudes that may contradict government and other institutional opinions. (These interventions obviously may come with their own complications.)

Secondly, the research on which this article is based (Frank 2006:31-72) found that patients often make an association between ART and death, especially since death may occur after the commencement of treatment. Hence, it is recommended that adequate psycho-education in respect of HIV, immunity and ARVs be conducted in an effort to challenge such associations.

'Because...you tell him or her about medication, they tell you, "You know, someone was telling me their big brother was taking this medication and now he's dead." And me, I'm advising him that "You don't know how sick was that guy was. You don't know his CD4 count. You don't know how long he's been sick." We can be HIV together but we can't die together and we can't face it like the same... Just imagine, this person is sick and then takes ARVs. $A R V s$ got side effects. Where are those side effects? They're going to be to him or her. So, when they think about that someone who died, they think maybe these tablets kill him/her.'

(Patient 3)

Thirdly, adherence interventions should include explanations of the role of additional treatment, such as vitamins in the treatment programme, that is, that they serve to boost the body's immune system but do not serve to suppress the virus. Hence, there needs to be an emphasis on the additional medication as a possible supplement (that is, in cases where it does not decrease the efficacy of the ART), rather than as a substitute for ART.

\section{DISCUSSION}

An analysis of the recommendations by the experts and patients for improving adherence has yielded some interesting findings. Both groups of participants recommended that enhancing social support, as well as implementing time-keeping mechanisms, are important in improving adherence. However, both experts and patients also generated a few substantively different recommendations. Below we attempt to explain the differences in recommendations.

One of the reasons for the different recommendations generated in the interviews with the patients and the expert participants could be their different circumstances and experiences. The expert participants' recommendations were based on at least two years of working within the HIV/AIDS field. Furthermore, their opinions were based on their specific training (in addition to their exposure to others' experiences), which influenced the manner in which they conceptualised the issues pertaining to adherence. This could explain why Expert 4 (a psychologist and researcher by training) offered many psychological explanations to account for patient behaviour, while Experts 1 and 3, who provide direct medical care to patients, offered suggestions of a more practical, as opposed to theoretical, nature. Expert 2 reported to be currently on ART, and hence his opinions were based not only on his work experience but also on his personal experience of receiving ART.

The patients' recommendations were largely based on their own personal experiences of the medication. Consequently, they focused on what they felt were the 'real-life', practical issues that influenced their levels of adherence. This was based on their own perceptions of which aspects of their lifestyle and behaviour influenced their adherence to their medication regime.

It can also be assumed that the expert participants were exposed to a wide range of HIV-positive patients' experiences upon which to base their recommendations. By virtue of the nature of their work, expert participants are in contact with numerous HIVpositive patients, and routinely deal with issues pertaining to adherence to ART. Although it is acknowledged that the patients themselves may also know many other HIV-positive patients, it is unlikely that they would encounter as many different patients every day, as would the experts.

When comparing the experts' and patients' responses it was found that the experts' recommendations for improving adherence appeared to be focused on interventions at a more systemic level while the patients' recommendations seemed to be focused on barriers experienced at a more personal level. An example of this is the recommendation by the patient participants that sharing success stories about ARVs should be encouraged, which differs fundamentally from the experts' recommendation that issues around poverty should be focused on to improve adherence levels. This difference could partly be explained by the fact that the patients, who are directly affected by the barriers to ART, tend to examine what they appear to have most control over, namely their own lives. Conversely, the experts' training equips them with insights to examine factors from a more systemic perspective. To the patients, HIV/AIDS and ART are personal battles, and the presence of HIV/AIDS in their lives is probably so overwhelming that all they can focus on is the condition's direct impact on themselves. On the other hand, to the experts, these issues cannot be separated from the political, economic and social contexts of the country, hence the nature of their recommendations.

Another point of interest is that the patient participants did not mention any recommendations in respect of traditional medicine and other practices. This could be explained by the fact that they 
most probably do not view traditional medicine as effective as, or perhaps as incompatible with, ARV treatment. Another explanation may be their assumptions about what the researcher may be receptive to. Further research in respect of this issue is clearly indicated.

It is evident that the patient and expert participants do view adherence to ARVs differently, and this could raise questions about the relative importance of the two groups recommendations. Each set of participants is armed with its own set of views and knowledge. The experts are equipped with more 'sophisticated' theoretical knowledge as well as experiential knowledge based on their interaction with numerous patients, while the patients are equipped with invaluable knowledge of their own experiences of taking ARVs. To weigh up one set of recommendations against the other would be naïve and unproductive, since each group of participants can be considered to be equipped with the expertise to make sense of issues pertaining to adherence in its own ways. Instead, it might be more productive to see these sets of recommendations as complementary and offering valuable insights at different levels (Van Vlaenderen \& Neves 2004:565-576).

\section{CONCLUSION}

This study has yielded a range of valuable recommendations from patients and experts. These recommendations, and particularly the differences reflected in the two sets of recommendations, have many implications for the way in which patients, healthcare workers and researchers think about adherence. Specifically, they alert us to the reality that adherence is a concept that has to be confronted at various levels, from the individual to the community. The knowledge of the patients may help to generate recommendations for improving adherence at the level of the individual while the 'academic' knowledge and professional expertise of the experts may help us to conceptualise the problem of adherence at a more systemic or global level.

Collectively, the findings reported in this article lead to the suggestion that the views of both experts and patients should be taken into account when planning adherence interventions. The findings also clearly suggest a need for further, more in-depth research on patient and expert recommendations for adherence to ART.

This study obviously has various limitations, including the following: Firstly, the limited number of participants included in this study has obvious implications for the generalisability of the research findings. Secondly, the method of data analysis employed in the study perhaps did not allow for a sufficiently nuanced engagement with the data collected. However, given that this is essentially an exploratory, qualitative study, these lacunae do not fundamentally undermine the value of the findings generated by this study. Indeed, these findings serve as valuable pointers for future research.

\section{REFERENCES}

Akula, S.L., 2002, 'Do heterosexuals with HIV/AIDS face discrimination and stigma after disclosure: A study conducted in a city (Visakhaptanam) in India', paper presented at International Conference AIDS, Andhra University, Visakhapatnam, India, 7-12 July.

Berg, K.M., Demas, P.A., Howard, A.A., Schoenbaum, E.E., Gourevitch, M.N. \& Arnsten, J.H., 2004, 'Gender differences in factors associated with adherence to antiretroviral therapy', Journal of General Internal Medicine 19(11), 1111-1117.

Brief, D.J., Bollinger, A.R., Vielhauer, M.J., Berger-Greenstein, J.A., Morgan, E.E., Brady, S.M., Buondonno, L.M. \& Keane, T.M., 2004, 'Understanding the interface of HIV, trauma, post-traumatic stress disorder, and substance use and its implications for health outcomes', AIDS Care 16(1), 97-120.

Buick, D., Fisher, M., Horne, R. \& Leake, H., 2004, 'Doubts about necessity and concerns about adverse effects: Identifying the types of beliefs associated with non-adherence to HAART', International Journal of STD and AIDS 15(1), 38-44.

Burke, L.E., Dunbar-Jacob, J.M., Schlenk, E.A. \& Matthews, J.T., 1998, 'Predictors of patient adherence: Patient characteristics', in S.A. Shumaker, E.B. Schron, J.K. Ockene \& W.L. McBee (eds.), 1984, The handbook of health behaviour change, 2nd edn., pp. 5-31, Springer Publishing, New York.

Butler, A., 2005, 'The negative and positive impacts of HIV/ AIDS on democracy in South Africa', Journal of Contemporary African Studies 23(1), 1-24.

Chung, W.Y.R., Lam, S.W.C., Lau, T.F.J., Li, C.K.P., Nahas-Lopez, V. \& Molassiotis, A., 2002, 'Factors associated with adherence to antiretroviral medication in HIV-infected patients', International Journal of STD and AIDS 13, 301-10.

Frank, J., 2006, 'Exploring expert and patient opinions and recommendations regarding antiretroviral treatment compliance', Unpublished MA (Counselling Psychology) research report, University of the Witwatersrand.

French, T., Weiss, L., Waters, M., Tesoriero, J., Finkelstein, R. \& Agins, B., 2005, 'Correlation of a brief perceived stress measure with nonadherence to antiretroviral therapy over time', Journal of Acquired Immune Deficiency Syndromes 38(5), 590-597.

Gifford, A., Bormann, J., Shively, M., Wright, B., Richman, D. \& Bozzette, S., 2000, 'Predictors of self reported adherence and plasma HIV concentrations in patients on multidrug antiretroviral regimens', Journal of Acquired Immune Deficiency Syndromes 23(5), 386-395.

Godin, G., Cote, L., Naccache, H., Lambert, L.D. \& Trottier, S., 2005, 'Research group on behaviours in the field of health', AIDS Care 17(4), 493-504.

Halkitus, P.N., Kutnick, A.H. \& Slater, S., 2005, 'The social realities of adherence to protease inhibitor regimens: Substance use, health care and psychological states', Journal of Health Psychology 10(4), 545-558.

Haynes, R.B., 2001, 'Improving patient adherence: State of the art, with a special focus on medication taking for cardiovascular disorders', in L.E. Burke \& I.S. Ockene (eds.), Compliance in healthcare and research, Futura Publishing, New York.

Heckman, B.D., Catz, S.L., Heckman, T.G., Miller, J.G. \& Kalichman, S.C., 2004, 'Adherence to antiretroviral therapy in rural persons living with HIV disease in the United States', AIDS Care 16(2), 219-230.

Ickovics, J.R. \& Meade, C.S., 2002, 'Adherence to HAART among patients with HIV: Breakthroughs and barriers', AIDS Care 14, 309-318.

Kalichman, S.C. \& Rompa, D., 2003, 'HIV treatment adherence and unprotected sex practices in people receiving antiretroviral therapy', Sexually Transmitted Infections 7(1), 59-61.

Kimmerling, M., Wagner, G. \& Ghosh-Dastidar, B., 2003, 'Factors associated with accurate self-reported adherence to HIV antiretrovirals', International Journal of STD and AIDS, 14(4), 281-284

Kumarasamy, N., Safren, S.A., Ramimani, S.R., Pickard, R., James, R., Krishnan, A.K.S., Soloman, S. \& Mayer, K.H., 2005, 'Barriers and facilitators to antiretroviral medication adherence among patients with HIV in Chennai, India: A qualitative study', AIDS Patient Care and STDs 19(8), 526537.

Lucas, G.M., Wu, A.W. \& Cheever, L.W., 2004, 'Adherence to antiretroviral therapy: An update of current concepts', Current HIV/AIDS Reports 1(4), 172-180.

Malan, J., 2003, HIV in our lives. A book of information sheets for people living with HIV, support groups and clinics, AIDS Law Project \& Treatment Action Campaign, Johannesburg.

Mann, T. \& Roberts K.J., 2000, 'Barriers to antiretroviral medication adherence in HIV-infected women', AIDS Care $12,377-386$

Mannheimer, S., Hirsch, Y. \& El-Sadr, W., 1998, 'The impact of the ALR alarm device on antiretroviral adherence among HIV-infected outpatients in Harlem', International Conference AIDS 12, 585-586. 
Max, B. \& Sherer, R., 2000, 'Management of the adverse effects of antiretroviral therapy and medication adherence', Clinical Infectious Diseases 30(2), S96-S116.

May, J., Govender, J., Budlender, D., Mokate, R., Rogerson, C. \& Stavrou, A., 1998, Poverty and inequality in South Africa: A report prepared for the Office of the Executive Deputy President and the Inter-Ministerial Committee for Poverty and Equality, viewed 24 March 2005, from http://www. polity.org.za/html/govdocs/reports/poverty/html.

Mbali, M., 2004, 'The Treatment Action Campaign and the History of Rights Based Patient-Driven HIV/Aids Activism in South Africa', Research Report no. 9, Centre for Civil Society, University of Kwazulu-Natal.

Meredith, K., Jeff, D.B., Mundy, L.M. \& Fraser, V.J., 2001, 'Sources influencing patients in their HIV medication decisions', Health Education and Behavior 28(1), 40-50.

Moosa, M.Y.H., Jeenah, F.Y. \& Vorster, M., 2005, 'HIV in South Africa - depression and CD4 count', South African Journal of Psychiatry 11, 12-15.

Murphy, D.A., Marielich, W.D., Hoffman, D. \& Steers, W.N., 2004, 'Predictors of antiretroviral adherence', AIDS Care 16(4), 471-484.

Phillips, K.D., Moneyham, L., Murdaugh, C., Boyd, M.R., Tavakoli, A., Jackson, K. \& Vyavaharkar, M., 2005, 'Sleep disturbance and depression as barriers to adherence', Clinical Nursing Research 14(3), 273-293.

Popp, D. \& Fisher, J.D., 2002, 'First, do no harm: A call for emphasizing adherence and HIV prevention interventions in active antiretroviral therapy programs in the developing world', AIDS: Official Journal of the International AIDS Society 16(4), 676-678.

Rothlind, J.C., Greenfield, T.M., Bruce, A.V., Meyerhoff, D.J., Filenniken, D.L., Lindgren, J.A. \& Weiner, M.W., 2005, 'Heavy alcohol consumption in individuals with HIV infection: Effects on neuropsychological performance', International Neuropsychological Society 11(1), 70-83.

Samet, J.H., Horton, N.J., Meli, S., Dukes, K., Tripps, T., Sullivan, L. \& Freedberg, K.A., 2005, 'A randomised controlled trial to enhance antiretroviral therapy adherence in patients with a history of alcohol problems', Antiviral Therapy 10(1), 83-93.

Seedat, M., Duncan, N. \& Lazarus, S. (eds)., 2001, Community psychology, theory, method and practice, Oxford University Press, Cape Town.
Shernoff, M., 2001, 'HIV Medication Adherence', FAMA Five Borough AIDS Mental Heath Alliance, 3(2), viewed 16 April 2004, from http://www.gaypsychotherapy.com/murray. htm.

Silverman, D., 1999, Interpreting qualitative data: Methods of analysing talk, text and interaction, Sage, London.

South African Department of Health, 2004, National antiretroviral treatment guidelines, Jacana, Johannesburg.

Stone, V.E. \& Smith, K.Y., 2004, 'Improving adherence to HAART', Journal of the National Medical Association 96(2), 27s-29s.

Tindall, C. 2006. Issues of evaluation, in P. Banister, E. Burman, I. Parker, M. Taylor \& C. Tindall (eds.), Qualitative methods in psychology: A research guide, pp. 142-159, Open University Press, Berkshire.

Titscher, S., Meyer, M., Wodak, R. \& Vetter, E., 2000, Methods of text and discourse analysis, pp. 76-91, Sage, London.

Tobias, B.Q., 2001, 'A descriptive study of the cultural mores and beliefs toward HIV/AIDS in Swaziland, Southern Africa', International Journal for the Advancement of Counselling 23, 99-113.

Treatment Action Campaign (TAC), 2006, 'Adherence and HIV resistance', viewed 27 September 2006, from www.tac.org. za/Documents/Literacy/Adherence.pdf.

Turner, B.J., Laine, C., Cosler, L. \& Hauck, W.W., 2003, 'Relationship of gender, depression, and health care delivery with antiretroviral adherence in HIV-infected drug users', Journal of General Internal Medicine 18(4), 248-257.

Van Vlaenderen, H. \& Neves, D., 2004, 'Participatory action research and local knowledge in community contexts', in D. Hook (ed.), Critical psychology, pp. 445-464, University of Cape Town Press, Cape Town.

Ware, N.C., Wyatt, M.A. \& Tugenberg, T., 2005, 'Adherence, stereotyping and unequal HIV treatment for active users of illegal drugs', Social Science E Medicine 61(3), 565-576.

Yun, L.W.H., Maravi, M., Kobayashi, J.S., Barton, P.L. \& Davidson, A.J., 2005, 'Antidepressant treatment improves adherence to antiretroviral therapy among depressed HIV-infected patients', Journal of Acquired Immune Deficiency Syndromes 38(4), 432-438. 